patient is dieted and under much better discipline. I have recently tried on in-patients at Malta doses containing $1 \frac{1}{2}$ grains of metallic mercury (that is, 10 centigrammes) on the so-called early, abortive plan, and the result has been no better than with a smaller dose, and not infrequently toxic symptoms developed about the fifth dose.

In the first report of the Advisory Board on Venereal Diseases in the Army it is stated on p. 12: "In certain cases ..... mercury ceases to be absorbed, and what has previously been absorbed is not eliminated. This condition known as mercurial stasis involves great risk to the patient. This is especially the case when injections of insoluble preparations are being made use of, as a large quantity may be introduced into the tissues with serious or fatal consequences when absorption again commences." In some 20 to 25 deaths on record under injections of insoluble preparations, mercurial stasis commonly occurred before death and could occur as long as two months after the last injection. This emphasises the important fact that insoluble preparations are by no means always regularly absorbed or eliminated.

My object in replying on Sept. 25th, 1909, to Dr. Pernet's article was to indicate possible dangers from a too purely routine use, or from too large doses of insoluble grey oil, and so obviate, if one could, any possibility of a repetition of the numerous accidents that arose from the abuse of mercury a century ago, which, for a time, led to the disuse of our most valuable agent in the treatment of syphilis, when judiciously administered.-I am, Sir, yours faithfully,

Malta. H. C. French, Major, R.A.M.C.

\section{INFLUENZA WITH SCARLATINIFORM RASH.}

To the Editor of THE LANCET.

SIR,-Influenza is, of course, by no means the only infectious disease which occasionally shows a rash simulating the rash of scarlet fever. There is, for instance, the prodromal scarlatiniform rash which occasionally precedes the characteristic rash of small-pox. (It is true that the distribution of the scarlatiniform rash in small-pox, together with the other symptoms, should prevent a mistake in diagnosis, but in my experience in connexion with fever hospitals $I$ have known a case notified as scarlet fever and recommended for admission to the ordinary scarlet fever wards.) Occasionally a scarlatiniform rash is seen as a prodromal rash in measles, or diphtheria, or even typhoid fever or chicken-pox. Indeed, in my opinion, any septicæmia may give rise to such a rash, and therefore, of course, a diagnosis of scarlet fever should never be based on a rash alone, though it is always safe to conclude that a scarlatinal rash indicates the probability of an infective germ at work, and that the case should be promptly isolated at home. A careful investigation even at the first visit will almost invariably secure a sufficient amount of evidence to make a correct provisional diagnosis, which in the majority of the more doubtful cases will probably be amply confirmed at the next visit.

$$
\text { I am, Sir, yours faithfully, }
$$

Norwich, Dec. 31st, 1909. J. I. O. NASH.

\section{A MEDICAL BRANCH OF THE NAVY LEAGUE.}

\section{To the Editor of THE LANCET.}

SIR,-A proposal has been made to form a branch of the Navy League. which shall consist entirely of medical men, irrespective of political opinions. Our profession has lent invaluable aid to various movements in the past, and there is no object more worthy of our support than the one which deals with the first line of defence in this country. Knowing the exceptional opportunities which medical men possess of discussing questions with all grades of society it seems only right thit some organised attempt should be made by the profession to use these opportunities, and thus further the interests of an object which so closely affects the welfare of the Empire. The Navy League has proved of such value in this country that a similar organisation has been founded elsewhere with such singular success that its membership now far exceeds that of the English League. We believe that if medical men choose to use the influence that they possess they can do a great deal towards advancing the claims of this league, and it is with this end in view that we the undersigned have formed ourselves into a provisional committee for the founding of a medical branch of the Navy League. The following are the rates of subscription : Vice-Presidents, $£ 5$ annually; Fellows, £1 $1 s$. annually; Members, 5s. annually.

All medical men who wish to join this branch are requested to send in their names to Dr. Maurice Craig, 54, Welbeck-street, London, W., who will forward the necessary form of of application for signature.

We are, Sir, yours faithfully,

W. H. Clayton Greene, Herbert S. Pendlebury, G. Lenthal Cheathe, Hugh M. Rigby,

MaUrice Craig, Risien Russeli,

JOHN FAWCETT,

ALFRED D. FRIPP,

W. P. HERRINGHAM,

ARTHUR Latham,

W. T. LISTER,

LEWIS SMITH.

R. Percy Smith,

J. M. G. SWAINSON,

H. Campbell Thomson,

E. D. Macnamara,

Jan. 4th, 1910.

\section{THE INDICATIONS FOR OPERATION.}

\section{To the Editor of THE LANCET.}

Srr,-It seems advisable that an early protest should be entered against the latest development of the lust for operation with which, judging from Mr. B. G. A. Moynihan's article in your issue of Jan. 1st, we seem to be threatened. We have in recent times seen inoffensive mobile kidneys proclaimed to be so great a danger as to demand immediate operation. We have seen appendicular affections elevated into a species of cult, imposing upon every practitioner who valued his reputation the necessity for reading into any abdominal pain so imminent a menace to life as to require the instant removal of perfectly normal appendices.

Now, forsooth, if Mr. Moynihan is successful in obtaining disciples, we are about to witness the unedifying spectacle of people with simple indigestion being hurried to the table to undergo an operation for duodenal ulcer. The road is to be a royal road. "It is therefore not necessary to the attaining of an accurate diagnosis that an examination of the patient should be made. The anamnesis is everything, the physical examination is nothing."

And this "anamnesis," what does it reveal? It reveals the ordinary classical symptoms of acid dyspepsia, as described in a thousand text-books, and successfully treated by bismuth and soda by millions of practitioners. Only this, and nothing more.

As I transcribe the above astounding passage I pause to wonder whether, after all, Mr. Moynihan is not indulging in a joke. If he is, I may perhaps be allowed the reflection that his jocularity is something lacking in polish, but if he is not joking I feel sure that $I$ am not the only person who will feel that his teaching is seriously lacking in qualities which are even more important than polish.

I am, Sir, yours faithfully,

Harley-street, W., Jan. 1st, $1910 . \quad$ LEONARD WILlIAMS.

\section{GUERNSEY SUNSHINE, 1909.}

\section{To the Editar of THE LANCET.}

SIR, - During the past gloomy year 1967 hours of sunshine have been registered in Guernsey. I think this means that Guernsey holds the record for the year in the British Isles, as it has done on many previous occasions.

I am, Sir, yours faithfully, Hy. Draper Bishop,

Medical Officer of Health, States of Guernsey.

Health Office, Guernsey, Jan. 3rd, 1910. 